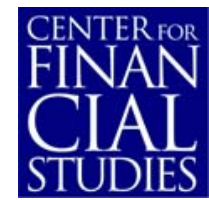

No. $2006 / 25$

Stock Market Interactions and the Impact of Macroeconomic News - Evidence from High Frequency Data of European Futures Markets

Bea Canto and Roman Kräussl 


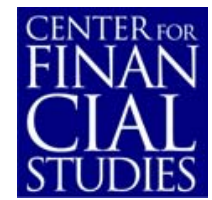

\section{Center for Financial Studies}

The Center for Financial Studies is a nonprofit research organization, supported by an association of more than 120 banks, insurance companies, industrial corporations and public institutions. Established in 1968 and closely affiliated with the University of Frankfurt, it provides a strong link between the financial community and academia.

The CFS Working Paper Series presents the result of scientific research on selected topics in the field of money, banking and finance. The authors were either participants in the Center's Research Fellow Program or members of one of the Center's Research Projects.

If you would like to know more about the Center for Financial Studies, please let us know of your interest.

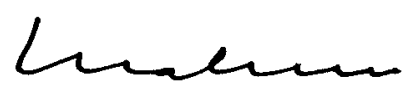

Prof. Dr. Jan Pieter Krahnen

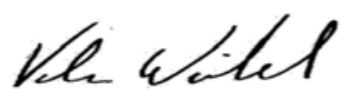

Prof. Volker Wieland, Ph.D. 


\title{
Stock Market Interactions and the Impact of Macroeconomic News - Evidence from High Frequency Data of European Futures Markets*
}

\author{
Bea Canto ${ }^{1}$ and Roman Kräussl ${ }^{2}$ \\ Preliminary Version \\ June 2006
}

\begin{abstract}
:
This study analyzes the short-term dynamic spillovers between the futures returns on the DAX, the DJ Eurostoxx 50 and the FTSE 100. It also examines whether economic news is one source of international stock return co-movements. In particular, we test whether stock market interdependencies are attributable to reactions of foreign traders to public economic information. Moreover, we analyze whether cross-market linkages remain the same or whether they do increase during periods in which economic news is released in one of the countries. Our main results can be summarized as follows: (i) there are clear short term international dynamic interactions among the European stock futures markets; (ii) foreign economic news affects domestic returns; (iii) futures returns adjust to news immediately; (iv) announcement timing of macroeconomic news matters; $(v)$ stock market dynamic interactions do not increase at the time of the release of economic news; ( $v i$ ) foreign investors react to the content of the news itself more than to the response of the domestic market to the national news; and (vii) contemporaneous correlation between futures returns changes at the time of macroeconomic releases.
\end{abstract}

JEL Classification: G14, G15

Keywords: Market Microstructure, Stock Market Dynamic Interactions, Macroeconomic News, High Frequency Data, VAR Modeling, Variance Decomposition

\footnotetext{
* We are grateful to Charles Goodhart, Richard Payne, Mark Salmon, and seminar participants at London School of Economics, Financial Markets Group, Tinbergen Institute and Bank of England.

1 Bea Canto, Watson Wyatt Brans \& Co., Postbus 75201, 1070 AE Amsterdam, The Netherlands, Tel.: +31 205433000 , Fax: +31 20 5433995, Email: Bea.Canto@watsonwyatt.nl

2 Roman Kräussl, Free University of Amsterdam and Center for Financial Studies Frankfurt/Main. Address at FU: Department of Finance and Financial Sector Management, FEWEB, de Boelelaan 1105, 1081 HV Amsterdam, The Netherlands, Tel.: +31 20 5986102, Fax: +31 20 5986020, Email: rkraeussl@feweb.vu.nl
} 


\section{Introduction}

The increasing availability of high frequency data allows performing more detailed research on the financial market microstructure. Empirical analysis of high frequency data on financial markets has yielded interesting results on, for instance, the volatility distribution of asset prices, dynamic relationships between stock indices and their corresponding futures contracts and the impact of news on asset markets. ${ }^{1}$ However, a still unresolved empirical question is how European stock markets respond to movements on other stock exchanges in the short-term. To our knowledge, this analysis is the first empirical attempt to characterize price interactions in three important European futures markets: the German, the Pan-European and the British using high frequency data, namely, using minute-by-minute returns. In addition, we analyze the role of macroeconomic news as a source of international equity market linkages.

Interdependence among national stock markets has been widely analyzed. Early studies, for instance Grubel and Fadner (1971), have found that interdependence of share price movements is much less pronounced among countries than within a country. More recent works have paid considerable attention to the structure of interdependence among national stock markets. Most empirical research has focused on stock returns rather than on stock prices. A partial list of such work includes Eun and Shim (1989), Campbell and Hamao (1992), Bekaert and Harvey (1995), and Ammer and Mei (1996). Recognition of the non-stationary property of stock prices had led other researchers to explore possible long-run relations among national stock markets, using the notion of cointegration, as formally defined in Engle and Granger (1987). Kasa (1992), Malliaris and Urrutia (1992), and Francis and Leachman (1998) found evidence of long-run interdependence of major stock market prices. However, these studies generally fail to address the contemporaneous structure of interdependence amongst international stock markets.

Previous empirical studies of the dynamic relationship of the major world stock price indices use monthly, weekly or daily data to investigate the interdependence of stock markets. Eun and Shim (1989) use a Vector Autoregressive (VAR) model to report a substantial amount of interdependence among national stock markets. King and Wadhwani (1990), in a study of the period at the time of the 1987 stock market crash, document how price movements in one market are transmitted to other markets. More recent papers use Vector Error Correction (VECM) specifications to study the links between the European and the U.S. stock markets (Gerrits and Yuce (1999) and Bonfiglioli and Favero (2005)), between the Latin American markets (Cheng, Firth and Meng (2002)) or between Asian emerging markets (Masih and Masih (1999)).

With respect to the literature on lead-lag relationships between markets for related assets using high frequency data, a large number of studies investigate the dynamic interactions between stock index and futures prices or between ADRs and stock prices. Most of this literature focuses on the U.S. or the U.K. financial markets. For instance, Hasbrouck (2003) empirically investigates the intraday price discovery in the U.S. equity index markets. Arbitrage opportunities between the index and its futures contract imply that the price series are cointegrated, suggesting a VECM to study the price leadership in these markets. Abhyankar (1995) and Gwilym and Buckle (2001) also use a VECM to examine the lead-lag relationship between the FTSE 100 index and the derivatives contracts, which are based upon it. The aim of these papers is to determine how movements in prices are transmitted between markets for related assets.

\footnotetext{
${ }^{1}$ See the recent surveys by Biais, Glosten and Spatt (2005), Stoll (2003) and Madhavan (2000).
} 
In this study, the temporal interrelationships between three geographically associated markets are analyzed. From an econometric perspective, its focus is similar to the one in this branch of literature as we employ the asem econometric techniques as the ones used in these papers. Using one-minute return data, our analysis tests and rejects any cointegration relationship between the DAX, the Eurostoxx 50 and the FTSE 100 futures contracts. Accordingly, a VAR approach is used to examine the intraday interdependencies between the futures returns on the three indices.

In recent years there has been a growing literature looking at the impact of macroeconomic announcements on U.S. and U.K. financial assets. The majority of these studies uses regression analysis where the announcements are included as exogenous variables in the Ordinary Least Square regressions. For example, Gwilym et al. (2001) investigate the impact of U.K. scheduled macroeconomic news announcements on the FTSE 100 and on the short sterling futures contracts. Similarly, Clare and Courtenay (2001) investigate the effects of U.K. macroeconomic news on selected futures contracts. They use a non-parametric test to document the initial reaction of London International Futures and Options Exchange contracts to a wide set of scheduled announcements. Our study also analyzes the effect of macroeconomic news on stock market returns. Nevertheless, it needs to be emphasized that the focus of our study is not to characterize the effects of a particular item of news on the stock returns, but to study whether the dynamic interactions between the DAX, the Eurostoxx 50 and the FTSE 100 futures returns change when macroeconomic data is released.

A large number of studies document the impact of economic news on exchange rate volatility or on the returns themselves. Examples are Almeida, Goodhart and Payne (1998) and Andersen, Bollerslev, Diebold and Vega (2003). These two papers compare the effects of pre-scheduled news (U.S. news in both cases) with the effects of non-scheduled releases (German news). Both studies report that the reaction of the exchange rates to the U.S. scheduled announcements is different from the reaction to the German non-scheduled announcements. In addition to their results, our study demonstrates that the announcement timing affects the intraday co-movements between the different stock exchanges.

While previous research shows that home country macroeconomic surprises influence home country asset prices, few studies investigate the influence of domestic announcements on foreign stock prices. Becker, Finnerty and Friedman (1995) attribute the interactions between the U.K. and the U.S. stock markets to U.S. economic information, namely to the "public information hypothesis". In particular, they study the response of U.K. equities during the half-hour following the U.S. economic announcements at 14:30h London time. They find that the correlation between the FTSE 14:30h-15:30h and the U.S. overnight returns is higher on announcement days that on non-announcement days. However, they can not study the short-term interactions between both stock exchanges following the announcement minutes because the U.S. stock exchange is not open by then. Our data set allows us to investigate how domestic announcements affect the short-term interactions between different markets.

Based upon on a different argument, Connolly and Wang (2003) explain the return co-movements for the U.S., U.K. and Japanese equity markets with an imperfect learning theoretical model. They examine the return co-movements in these equity markets with a focus on the distinction between economic fundamentals and contagion. Their results show that the bulk of observed co-movements in returns of the international equity markets cannot be attributed to public information about economic fundamentals. 
This study is linked to these papers because we also analyse the co-movements between different stock prices. We analyze if these co-movements can be attributed to the public information flow, as measured by the news on macroeconomic fundamentals. However, our analysis differs from theirs since we use a microstructure approach and our focus of attention is the short term effects exploiting the microstructure information contained in our high frequency data set.

The recent availability of high frequency datasets from different stock exchanges allows investigating short-term international stock market interactions. The data used in this research consists of minute-by-minute futures prices for the FTSE 100, the DAX and the DJ Eurostoxx 50 indices. To our knowledge, this is the first empirical research that explores the short-term return spillovers between the Eurostoxx, the DAX and the FTSE futures returns. With respect to the role of economic news in explaining stock returns co-movements, this research is to our knowledge the first analysis that incorporates German and Pan-European news to investigate international returns spillovers.

To start with, this study investigates the short-term dynamic spillovers between the futures returns on the DAX, the DJ Eurostoxx 50 and the FTSE 100. This analysis is extended by examining whether economic news is one source of international stock return co-movements. In particular, we test whether stock market interdependencies are attributable to reactions of foreign traders to public economic information. To the extent that there are common factors in business cycles, macroeconomic news in one country may reveal information about future cash flows or discount rates in many countries, not just in the home country. This observation suggests that one source of market return co-movements may be macroeconomic announcements. Connolly and Wang (2003) and McQueen and Roley (1993) present evidence to test this "public information hypothesis". In order to evaluate this view, we examine the question of how the stock indices react to economic information emanating from Germany, the Eurozone and UK. In the final step, we investigate how the intermarket relationships change at the time of economic news releases. Thus, we analyze whether cross-market linkages remain the same or whether they do increase during periods in which economic news is released in one of the countries. ${ }^{2}$

Our main results can be summarized as follows: (i) there are clear short term international dynamic interactions among the European stock futures markets; (ii) foreign economic news affects domestic returns; (iii) futures returns adjust to news immediately; (iv) announcement timing of macroeconomic news matters; (v) stock market dynamic interactions do not increase at the time of the release of economic news; (vi) foreign investors react to the content of the news itself more than to the response of the domestic market to the national news; and (vii) contemporaneous correlation between futures returns changes at the time of macroeconomic releases.

The remainder of this paper is organized as follows. Section II introduces the dataset and some preliminary statistical analysis. Section III describes the methodology. Section IV discusses the empirical results. Section IV.1 presents the results on the dynamic relationships among the European stock returns. Section IV.2 investigates how the economic news is transmitted across markets. Section IV.3 examines how the cross-market relationships change in the minutes after the release of economic data. Finally, Section V draws the conclusions.

\footnotetext{
${ }^{2}$ Investigation of the above issues can test the efficiency of European futures markets and the existence of a lead-lag relationship between European stock indices. The results in this analysis give some insight into changes in stock market interactions at the time of economic announcements. If markets are efficient, price adjustments to new information should be completed sufficiently quickly to avoid arbitrage windows. These points have crucial implications for investors' trading and hedging strategies.
} 


\section{Data and Preliminary Statistics}

We use real-time macroeconomic announcements and high frequency stock market returns to test our hypothesis. In particular, we use returns calculated over one-minute intervals. Such high frequency data allows us to probe the workings of the marketplace in powerful ways because: $(i)$ we avoid problems related to the existence of non-synchronous trading periods between countries (see Karolyi and Stulz (1996)); (ii) we measure more accurately the effect that macroeconomic news announcements have on stock prices (Andersen et al. (2003)) by focusing on episodes where the source of price revisions is well identified, thus leading to a high signal-to-noise ratio; and (iii) we are able to test the theoretical assumption that foreign news are first incorporated into foreign stock prices and only then into domestic stock prices.

The dataset of stock indexes futures contracts covers the period between 1 July and 31 August 2001. The intraday data consists of equally spaced thirty seconds snapshots of the most recent transaction price for the futures contracts published on the screens of Reuters Information Systems. The contracts included are the futures on the DJ Eurostoxx 50, on the DAX and on the FTSE 100 index.

The DJ Eurostoxx Index comprises the 50 Euro Zone (excluding U.K. and Switzerland) blue-chip companies with the largest free float market capitalization. ${ }^{3}$ The trading hours are 08:00h until 16:30h London time. ${ }^{4}$ The DAX is the German Stock Index, which comprises Germany's thirty largest market capitalization companies. Its futures contracts are also traded on the Eurex Stock Exchange between 08:00h and 16:30h. The FTSE 100 Index Futures are traded on the London International Futures and Options Exchange (LIFFE) between 08:00 and 17:30h. As our interest relays upon studying the dynamic interactions between the different exchanges, only the common trading hours are included in our analysis, namely intraday data between 08:00h and 16:30h.

Regarding zero observations, i.e. those minutes with one or two of the index returns equal to zero are substituted by the corresponding thirty seconds returns. The original data set includes the transaction prices for the contracts on, for instance, 2 July at 9:00:00h, at 9:00:30h, at 9:01:00h, etc. For example, if the DAX futures return between 09:00:00h and 09:01:00h is zero, the one minute return of the three series are substituted for the corresponding 30 seconds returns, i.e., the returns between 09:00:30h and 09:01:00h are calculated for each series. Otherwise, zero observations are left in the dataset as they contain information in our analysis, namely, no trades are crossed at that particular minute. In total 4.0 percent of the DAX returns, 9.1 percent of the Eurostoxx returns and 5.8 percent of the FTSE returns are equal to zero. After cleaning the data, the sample contains 21,790 one-minute observations for each of the futures on the DAX, Eurostoxx 50 and FTSE 100 indices.

We calculate returns over one-minute intervals. This return $R_{t}$ is defined as the log of the last transaction price of the current minute interval $P_{t}$ minus the log of the last transaction price of the previous minute interval $P_{t-1}$, i.e, $R_{t}=\ln \left(P_{t}\right)-\ln \left(P_{t-1}\right)$. Descriptive statistics of the returns are reported in Table 1A. The returns present typical features of high frequency data: the sample skewness is 0.0 for the three series, but the sample kurtoses are well above the normal value of 3 , which indicates that the returns are symmetric but fat-tailed relative to the normal distribution. The

\footnotetext{
${ }^{3}$ During the period between July and August 2001 the constituents of the index were sixteen French companies, thirteen German, seven Italian, seven Dutch, five Spanish, one Belgium bank and one Finnish company.

${ }^{4}$ All quoted times in the study correspond to London time.
} 
FTSE 100 futures contracts are the only ones that yielded on average positive returns during the sample period studied.

\section{TABLE 1 AROUND HERE}

Table 1B reports the sample autocorrelations of the futures price series and of the futures returns series for the DAX, the Eurostoxx 50 and the FTSE 100 stock indexes. The sample autocorrelations of all price series present very large values of first-order autocorrelation and die off very slowly, which indicates that futures prices are quite likely to be processes integrated of order one. The lower part of Table 1B documents the autocorrelations of the futures returns. Only the FTSE 100 returns present negative first order autocorrelation. This empirical finding has been previously documented by Glosten and Milgrom (1985). If the transaction prices bounce between the bid and the ask levels, a negative serial dependence is noted in the time series. A likely explanation for the fact that no observation is made of a negative first order autocorrelation with the DAX and Eurostoxx 50 returns may be that in our sample the intraday average bid-ask spread for the DAX futures contracts is 0.12 percent, for the Eurostoxx 50 futures contracts is 0.13 percent and for the FTSE 100 futures contracts the bid-ask spread is 0.23 percent, nearly twice as large as that on the previous contracts. ${ }^{5}$

Table 1C provides the correlation matrix of the stock index futures returns between the three markets. As expected, there are strong positive correlations between the three markets. In particular, the correlation between the DAX and the Eurostoxx 50 futures is 0.718. This high correlation is due to the fact that, as pointed out before, by 1 July 2001, thirteen out of the fifty members of the Eurostoxx 50 index were German companies, which represented 24 percent of the market capitalization of the index. This fact makes it worth testing whether there is any cointegration relationship between the future contracts. Would that be the case, then the future prices movements are driven by the same components in the long-term.

To test whether two series are cointegrated, first we test if each series is integrated of order one, i.e., I(1). Table 2A details the Augmented Dickey Fuller (ADF) unit root tests of stationarity in the levels and first differences of the futures price series (in natural $\log$ form) of the DAX, the Eurostoxx 50 and the FTSE 100. The test results show that the null hypothesis that futures prices levels are non-stationary is not rejected for the three markets. The null hypothesis that the first log differences in these futures indexes are non-stationary is strongly rejected. These results indicate that the price series of the futures on the DAX, the Eurostoxx and the FTSE follow an I(1) or nonstationary process and thus, should be differenced to achieve stationarity.

\section{TABLE 2 AROUND HERE}

The Johansen Cointegration test for each pair of prices is recorded in Table 2B. At the 5 percent significance level, the results in Table $2 \mathrm{~B}$ indicate that all the tests reject the existence of a cointegration relationship between the stock markets included in our analysis. In other words, the DAX, the Eurostoxx 50 and the FTSE 100 future prices do not share a long-term equilibrium. As a consequence, the appropriate econometric specification to model the dynamic interactions between the three futures markets is a VAR approach, and not a VECM.

The other part of our data set consists of Eurozone, British and German macroeconomic announcements covering the same period plus a market expectations series for each type of

\footnotetext{
${ }^{5}$ The bid-ask spread for the FTSE 100 futures contracts is particularly large at the beginning of the trading day. Between 08:00h and 09:00h the average spread is 0.72 percent.
} 
announcement. The expectations series are obtained from Money Market Services International. Using the expectations series enables us to classify the announcements into an unexpected and an expected component. The macroeconomic data series are supplemented with the inclusion of Monetary Policy Committee interest rates decisions by both the European Central Bank (ECB) and the Bank of England (BoE), - including 'no change' decisions -, the release of the weekly European Financial Statement of the ECB and the publication of the CIPS Service Reports and the Changes in Official Reserves for the U.K.

On the one hand, the Eurozone and the British releases reach the market at the official prescheduled announcement time. Eurozone macroeconomic data is generally released at 11:00h. The ECB interest rate decisions are scheduled at 12:45h.. British announcements are generally released at 09:30h and $\mathrm{BoE}$ interest rate decisions at 12:00h. On the other hand, German releases are not announced at regular prearranged times. To include the macroeconomic news data in our analysis, the series is classified according to the country of origin and their sign, i.e., if they represent good news for the market or bad news for the market. ${ }^{6}$ The full set of macroeconomic announcements used in our study is presented in Table A1 in the Appendix along with the days and release times.

\section{Methodology}

This section introduces the empirical framework for studying the dynamic interactions between the futures prices on the DAX, on the Eurostoxx 50 and on the FTSE 100 indices. From an econometric perspective, the Vector Autoregressive (VAR) approach is suitable for the analysis of dynamic linkages among the markets since it can capture the main cross-market interactions and it can simulate the responses of a given exchange to innovations in the other markets.

The initial model specification in this section is an unrestricted VAR approach on the returns of the three futures contracts. Each return is affected by its own lagged returns and the past movements on the other stock exchanges. The general form of the unrestricted VAR system is:

$$
R_{j, t}=\alpha_{j}+\sum_{j=1}^{3} \sum_{r=1}^{K} \beta_{j, r} R_{j, t-r}+u_{j, t} \quad t=1,2, \ldots, T
$$

where $R_{j, t}$ is the return of the index $j$ at time $t . j=\mathrm{DAX}$, Eurostoxx and FTSE indices. The $\beta_{j, r}$ measure the spillovers between markets $j$ and $j$ ' captured by lagged returns, where $K$ is the number of lags. $u_{j, t}$ is a vector white noise process with $E\left(u_{t} u_{t}{ }^{\prime}\right)=\Omega$ for all $t$. Notice that in absence of market restrictions and cost of capital, the constant term $\alpha_{j}$ should be zero. This initial VAR specification will be used to analyze the short-term dynamic spillovers between the future returns on the DAX, the Eurostoxx and the FTSE 100.

Next, to analyze the impact of news on stock market returns, the series of macroeconomic releases are introduced as exogenous variables in the VAR specification. The new VAR system is

$$
R_{j, t}=\alpha_{j}+\sum_{j=1}^{3} \sum_{r=1}^{K} \beta_{j, r} R_{j, t-r}+\sum_{i=0}^{6} \sum_{s=0}^{S} \theta_{i, s} x_{i, t-s}^{n e}+u_{j, t} \quad t=1,2, \ldots, T
$$

\footnotetext{
${ }^{6}$ Any economic activity that changes the cash flows and/or the discount rates affects stock prices. Good news such as a higher than expected value for Industrial Output causes a theoretical increase in the stock prices. On the opposite, a lower than expected sentiment index is included as bad news.
} 
for $j=$ DAX, Eurostoxx and FTSE. Each category of news $i$ is allowed to affect futures indices up to $S$ minutes after the news is released.

According to the efficient markets hypothesis, only the unexpected part of the announcements should have an impact on stock returns. If we denote $x_{t}$ as the actual announced economic figure at moment $t$ and $x_{t}^{e}$ as its correspondent expected value, then $x_{t}^{n e}=x_{t}-x_{t}^{e}$ represents the unexpected part of the release or the "news" contained in the announcements, which is included in our regression. The coefficients $\theta_{i, s}$ measure the impact of news on stock returns. Evidence supporting the "public information hypothesis" is collected by domestic news affecting foreign stock returns, namely if the coefficients $\theta_{i, s}$ are significant in the $R_{j, t}$ equation.

In practice we introduce the macroeconomic releases as exogenous dummy variables in the VAR equations. ${ }^{7}$ According to our classification of news, i.e., country of origin and sign of the surprises (see table A1 in the Appendix), we introduce six new dummy variables $x_{i, t}^{n e}$, where $i$ stands for positive and negative surprises emanating from British, Eurozone and German announcements. Each dummy variable is a series of zeros with observations equal to one on the minutes in which economic data is released. ${ }^{8}$

Finally, to assess whether the dynamic spillovers between the domestic and the foreign returns change during periods in which macroeconomic data is released, an interaction coefficient is introduced. Formally, we impose the following constraint on $\beta$ in equation (1):

$$
\beta=\beta^{0}+\beta^{1} x_{t}^{n e}
$$

This way we conjecture that the interactions between the international futures returns have some linear relation with the macroeconomic announcements measured by the variable $x_{t}^{n e}$. The coefficient $\beta^{1}$ captures the incremental impact of information releases on the lead-lag relationship between returns. To test if dynamic spillovers between futures returns change during the minutes after the announcements, we can directly test whether $\beta^{1}=0$. Equation (1) can be rewritten as follows:

$$
R_{j, t}=\alpha_{j}+\sum_{j=1}^{3} \sum_{r=1}^{K}\left(\beta_{j, r}^{0}+\beta_{j, r}^{1} x_{t}^{n e}\right) R_{j, t-r}+u_{j, t} \quad t=1,2, \ldots, T
$$

As in the previous equations $R_{j, t}$ corresponds to the return of market $j$ in minute $t$. A positive and significant coefficient $\beta^{\mathrm{l}}$ indicates that the lead of the domestic market strengthens in the wake of local macroeconomic news releases. On the other hand, a negative and significant coefficient $\beta^{1}$

\footnotetext{
${ }^{7}$ We include dummies instead of the unexpected value of the release in the analysis since the magnitude of different announcements can not be compared. For instance, a one percent increase in Industrial Output is not the same as a one point increase in the Economic Confidence Indicator.

8 Market efficiency requires that price adjustments to new information are completed sufficiently quickly to avoid unnecessary arbitrage windows, and so the speed of market adjustment to news may be used to judge the degree of market efficiency.
} 
provides evidence of a weakening in the lead of domestic returns at the time of domestic announcements.

One of the criticisms of the unrestricted VAR models is that the Impulse Response Function and the Decomposition of the Variance are sensitive to the assumed origin of shocks and to the order in which they are transmitted to other markets. We overcome this problem by using the Generalized Impulse Response and Variance Decomposition described by Pesaran and Shin (1998). The generalized functions are invariant to the reordering of the variables in the VAR. The generalized impulse responses from an innovation to the $j^{\text {th }}$ variable are derived by applying a variable specific Cholesky factor computed with the $j^{\text {th }}$ variable at the top of the Cholesky ordering.

As the system is just identified, we estimate the unrestricted VAR in equation (1) by applying OLS equation by equation. All the tests in this study are computed using heteroskedasticity and serial correlation consistent standard errors (HAC), which perform heteroskedasticity-robust inference about the coefficients and are asymptotically robust to residual heteroskedasticity unknown form.

\section{Discussion of Empirical Results}

\section{IV.1 Dynamic Spillovers between European Stock Exchanges}

This subsection presents the empirical results on the dynamic spillover effects between the futures returns on the DAX, on the Eurostoxx 50 and on the FTSE 100. Furthermore, it also assesses whether the transmission of price movements is symmetric or asymmetric with the London Stock Exchange. In particular we discuss the results of the estimation of our baseline VAR model in equation (1). The number of lags $K=9$ is chosen based on the Akaike Information Criteria (AIC).

The VAR estimates capture important cross-market linkages. For sake of space, the estimated coefficients of the VAR system are not reported. Instead, the Wald test is noted in order to examine whether the lagged domestic returns are jointly significant in the foreign returns equations and the generalized impulse response functions of the system and its variance decomposition are examined. Table 3 reports the $F$-statistics of the Granger Causality Tests.

\section{TABLE 3 AROUND HERE}

The significant $F$-statistics in Table 3 indicate that there are clear short-term dynamic interactions between the DAX, the Eurostoxx 50 and the FTSE 100 futures returns. This finding indicates that past returns in the foreign markets influence subsequent domestic returns. Figure 1 displays the impulse response functions, which dynamically simulate the VAR system (1).

\section{INSERT FIGURE 1 HERE}

Several interesting patterns of market returns interactions can be drawn from this figure. $(i)$ innovations in the domestic stock exchange are transmitted to foreign stock exchanges; (ii) all the markets attain the maximum response one minute after a shock in any foreign stock exchange has been introduced; (iii) the three futures react up to four or five minutes after the shock in one of the foreign markets has been introduced and (iv) domestic returns tend to reverse the returns realized in the preceding minutes and the effect of a shock upon the domestic market is internalized within the same minute of the introduction of the shock 
Finding (iii) points out that the DAX and the Eurostoxx 50 futures adjust to movements in the FTSE futures prices as fast as the FTSE adjusts to movements in continental European futures prices. Nevertheless, it is interesting to note that the magnitude of the initial response of the Eurostoxx to a shock in the FTSE 100 is larger than the initial response of the FTSE 100 to a shock in the Eurostoxx $50\left(2.25 \cdot 10^{-4}\right.$ vs. $\left.1.73 \cdot 10^{-4}\right)$. Our findings reveal that, even though the crossmarket spillovers are asymmetric with the FTSE 100 price movements, the FTSE 100 futures prices are not isolated from foreign futures prices movements. Finally, domestic returns tend to reverse returns realized in the preceding minutes and the effect of a shock upon the domestic market is internalized within the same minute as the introduction of the shock, which is consistent with the efficient market hypothesis.

The variance decomposition attempts to gauge to what extent the variance of certain markets are explained by other markets. The results in Table 4 demonstrate that most of the decomposition of the forecast error variance is picked up within the first minute after the shock has been introduced. The results in Table 4 also indicate that the DAX and the Eurostoxx 50 futures affect each other in a very similar way. Furthermore, the British futures market appears to be the most exogenous one, as most of its variance is explained by its own innovations; five minutes after the shock, 71.8 percent of the FTSE variance is explained by its own shocks, unlike the variances of 56.4 percent and 56.8 percent respectively of the DAX and the Eurostoxx 50 which are explained by their own innovations.

\section{INSERT TABLE 4 HERE}

These findings with respect to interdependencies between different stock exchanges could superficially appear to be inconsistent with market efficiency. A couple of observations concerning these results need to be made. First, the minute-by-minute average return changes are small. Thus, even if some predictive ability can be achieved with the analysis we performed, it may still not offset the transaction costs. Second, the extent to which the minute-by-minute fluctuations in stock markets can be explained by their immediately preceding time path is not large. The $R^{2}$ values of the three VAR equations fall into the range 0.012 to 0.024 .

To summarize, the results in this section show significant short-term dynamic spillovers between the LIFFE and the Eurex futures markets. Our empirical evidence suggests that the FTSE 100 futures are the most influential ones. However, our results do not display a clear lead-lag relationship pattern between the European stock exchanges in which, for instance, the FTSE 100 index leads the price evolution and continental European futures follow its movements. Furthermore, we find that the spillovers vanish within the next five minutes after a change in any of the futures prices, which indicates that these markets are efficient when responding to movements on other stock exchanges.

\section{IV.2 Macroeconomic News and Stock Market Returns}

This subsection presents the empirical results on how the futures returns react to economic information originating in Germany, the Eurozone and the U.K. To test for systematic effects of the news on the stock market returns, we repeat the analysis of the previous subsection including the effect of the economic news in the VAR system as specified in equation (2). In the estimation, the 
news is allowed to affect the evolution of stock prices up to ten minutes after the announcement has been released. ${ }^{9}$

From the cumulative estimated coefficients and the $F$-statistics reported in Panel A of Table 5 few points are worth noting: (i) as expected, domestic returns are mostly affected by domestic news releases; (ii) news identified as "good surprises" positively affects stock returns and news designated as "bad surprises" negatively affects stock returns; (iii) news on domestic macroeconomic data significantly affects foreign futures returns. In particular, German news always affects Eurostoxx 50 returns $(F$-Statistic $=2.341$ and 2.187$)$ and Eurozone negative news affects DAX returns $(F$-Statistic $=3.889)$; $(i v)$,our results also show that positive German news significantly affects the three futures returns. This finding suggests that British investors are also aware of macroeconomic news originating from continental Europe; $(v)$ British positive news significantly affect DAX returns $(F$-Statistic $=1.945)$ and Eurostoxx 50 futures returns $(F$-statistic $=1.675)$. This last effect is mainly due to the response of the markets to the cut in U.K. interest rates on 2 August, 2001. This last finding empirically supports the current literature on the effects of monetary policy on stock prices. Rigobon and Sack (2002) establish the links between monetary policy and stock prices and conclude that increases in short-term interest rates result in a decline in stock prices, which is consistent with our findings.

\section{TABLE 5 AROUND HERE}

The empirical results in Panel B of Table 5 indicate that future returns adjust to both domestic and foreign news immediately. The main effect of all the news on futures returns, except for positive German news, is within the same minute of the release. Moreover, the full response to the news occurs within two minutes of the release.

With respect to the British news, positive releases have a strong, significant effect on the FTSE 100 futures; its initial impact on the FTSE 100 returns is $\theta_{u p, 0}=0.718$. Positive announcements have a large and persistent effect not only on the FTSE contracts, but also on the Eurostoxx $50\left(\theta_{u p, 0}=\right.$ $0.438)$ and DAX $\left(\theta_{u p, 0}=0.456\right)$ indexes futures. Buckle, Gwilym, Thomas and Woodhams (1998) also study the effects of British news on the FTSE 100 future contracts. They include dummy variables to take news into account. Using five minute windows, they find that none of the dummy variables turns out to be significant. Accordingly, their results suggest that news does not affect the mean returns. On the contrary, our results indicate that British news does have an effect on stock prices but that the price adjustment to news takes less than five minutes. Regarding the timing of the adjustment, our results are in line with those of Clare and Courtenay (2001). For the FTSE contracts, they also illustrate that the mean returns peak in the first minute following the British announcements and then they decline sharply.

With respect to the Eurozone news, to our knowledge, no research has analyzed its effects on futures prices. Our results suggest that Eurozone announcements have a larger explanatory power than news originating from other countries on the Eurostoxx 50 futures price movements. Interestingly, we also find that Eurozone news immediately affects the DAX $\left(\theta_{e p, 0}=0.549\right.$ and $\theta_{e n, 0}$ $=-0.952)$ and the FTSE 100 futures returns $\left(\theta_{e p, 0}=0.247\right)$ in a significant way . Curiously, our results exhibit that the positive Eurozone news has an effect on stock returns of the form $\ldots . .0,0,+1,-$

\footnotetext{
${ }^{9}$ This means that in the VAR specification $S=10$ lags. Clare and Courtenay (2001) demonstrate that the abnormal activity for the FTSE 100 contracts lasts for around eight minutes after the British announcements. We tried the estimation with different lags orders up to thirty minutes and the news never affected stock returns more than two minutes after the announcement. Moreover, a negative $S$ was included before the official release times in the estimation to account for announcement leakage, but doing so proved unnecessary.
} 
$1,+1 \ldots$, i.e. the stock prices react positively within one minute of the release, there is a rebound after the initial news shock, but this rebound is then reversed. Other authors like Goodhart, Hall, Henry and Pesaran (1993) also document this initial overreaction of stock prices to macroeconomic news. However, it needs to be stressed that the initial effect of the news is always lower than 0.07 percent, the magnitude of this coefficient is not big enough to make systematic profits from the announcement release.

Unlike the other announcements, the German releases do not have pre-advertised release dates and times. Therefore, it is possible to examine how pre-scheduled announcements affect the response of stock exchanges to news. We would expect that futures returns response to non-scheduled announcements is completed more slowly than the response associated to scheduled releases. Table 5 shows that this is the case for positive German news. The markets do not react to the news within the first minute of its release but they react one minute later. We may think that international investors wait to observe the reaction of the DAX index and then respond as soon as the DAX index moves. However, the DAX index's response to positive German news also peaks one minute after the releases $\left(\theta_{g p,-1}=0.333 v s . \theta_{g p, 0}=0.297\right)$, which indicates that foreign investors react to the news itself and not the DAX index's response to the German news.

Overall, when the macroeconomic releases are included in our analysis, the news significantly affects the domestic futures returns as well as the international futures returns. This evidence supports the "public information hypothesis" and demonstrates the importance of economic information in explaining international equity market linkages. Furthermore, we find that the general response of the stock returns to news is very quick, characterized by a jump within the same minute and the minute following the announcement and little movement thereafter.

\section{IV.3 Effects of Macroeconomic News on Stock Market Interdependencies}

This subsection presents the empirical results on whether cross-market linkages remain the same or whether they increase in the minutes following the economic announcements. In other words, we investigate whether investors follow the FTSE index response to British news or whether they respond to the news itself. In the previous subsection IV.2 the discussion focused on how domestic news affects foreign futures returns. In this subsection we go one step further and investigate how interactions between domestic and foreign futures returns change around periods when macroeconomic data is released. In the first step, we analyze the changes in the lead-lag relationship between futures markets at the time of the announcements. In the second step, we focus on how the contemporaneous correlation between futures markets changes during the announcement releases.

To test the impact of macroeconomic releases on the lead-lag relationship between DAX, Eurostoxx 50 and FTSE 100 futures returns, interaction variables $x_{t}^{n e} * R_{i}$ are introduced into the system (3). These variables assume the value of one if observation $t$ lies within five minutes prior to the news releases or ten minutes after the news releases and zero otherwise. As in the previous section we include ten lags in the new estimation. Panel A of Table 6 shows mixed evidence regarding the effects of macroeconomic news on stock market spillovers. Regarding the British news, the sum of the lagging interaction variable coefficient is insignificant in most instances. The $F$-Statistic does not reject the null hypothesis that the sum of the lagging coefficients on the interaction variables is equal to zero at 10 percent level. This implies that our analysis exhibits no significant changes in the lead-lag relationship between the FTSE 100 and the continental European futures at the time of the British economic news releases. 


\section{TABLE 6 AROUND HERE}

Regarding the continental European news, several interesting patterns of market return comovements emerge; $(i)$ for the FTSE 100 equation the sum of the lagging interaction variable coefficients is negative and significant for the Eurozone news $\left(\beta_{e p,-1 \ldots-10}^{1}=-0.195\right.$ and $\beta_{e n,-1 \ldots-10}^{1}$ $=-0.038)$ and for the positive German releases $\left(\beta_{g p,-1 \ldots-10}^{1}=-0.221\right)$. This evidence implies that the lead of the Eurostoxx 50 futures over the FTSE 100 weakens around the time of Eurozone economic releases. Similarly, the lead of the DAX futures over the FTSE 100 returns weakens around the time of positive German news releases. This evidence suggests that British investors do not solely take into consideration the response of continental European investors to European news, at least in the next ten minutes following the releases; (ii) the feedback of the Eurostoxx 50 returns to the DAX market also weakens around the release of positive Eurozone information $\left(\beta_{e p,-1 \ldots-10}^{1}\right.$ $=-0.281$ and significant); (iii) the lead of DAX returns over Eurostoxx 50 strengthens following the release of positive German news $\left(\beta_{g p,-1 \ldots-10}^{1}=0.154\right.$ and significant); (iv) the remaining cumulative coefficients are not significant. This last result presents no evidence of meaningful changes in the lead-lag relationship of the futures markets around the time of economic news releases.

Panel B of Table 6 reports further evidence of the changes in the lead-lag returns relationship at the time of the economic releases. None of the individual estimated coefficients reported in this part of the table turn out to be significant at the 10 percent level. ${ }^{10}$ Nevertheless, the negative signs of most of the coefficients confirm the previous result that the lead of the domestic market does not strengthen during periods when domestic economic news is released.

In subsection IV.2 we concluded that domestic news affects foreign futures returns. The results of the analysis performed in this subsection provide some evidence of a weakening in the lead of the domestic returns at the time of national macroeconomic news releases. If both findings are pooled together they suggest that, in the short-term, international investors do not wait to see the response of domestic markets to local news, but directly react to the information contained in the news itself.

To beter understand how the stock market interactions change at the time of the announcement periods the contemporaneous correlations are analyzed. The contemporaneous correlation between futures returns when there are no macroeconomic announcement releases are given as: $\rho^{\mathrm{n}}=0.432$ for the pair FTSE-DAX, $\rho^{\mathrm{n}}=0.412$ for the pair FTSE-Eurostoxx 50 , and $\rho^{\mathrm{n}}=0.748$ between the DAX and the Eurostoxx 50 returns. Table 7 presents changes in the contemporaneous correlations around announcement minutes. Panel A of Table 7 notes a significant increase in the contemporaneous correlation between the futures returns on the five minutes following the announcement. Specifically, the contemporaneous correlation increases from $\rho_{u \text {,before }}=0.452$ to $\rho_{u, \text { after }}=0.492$ for the pair FTSE-DAX and from $\rho_{u, \text { before }}=0.315$ to $\rho_{u, \text { after }}=0.539$ for the pair FTSE-Eurostoxx.

Having a closer look at the minute-by-minute return cross-correlation, we observe that the main increase in the contemporaneous correlation between the FTSE 100 and the continental European returns is not on the same minute when the news is released, but one minute before the

\footnotetext{
${ }^{10}$ We repeat the estimation allowing the interaction variable to affect foreign returns up to thirty minutes. Neither the qualitative results nor the conclusions are altered. All the coefficients not reported in Table 6 are not significant.
} 
announcements. The high co-movements one minute before the announcement ( $\rho_{u,+1}=0.776 v s . \rho^{\mathrm{n}}$ $=0.432$ for the FTSE-DAX pair and $\rho_{\mathrm{u},+1}=0.777 v s . \rho^{\mathrm{n}}=0.412$ for the FTSE- Eurostoxx pair) are due to the fact that British news is pre-scheduled, namely that all market participants know the exact minute in which the news is made public.

A plausible explanation for these findings may be that one minute before the news releases investors in the different markets do not trade but they wait for the actual announcement figure, as they know new information is about to arrive onto the market. The lower magnitude of the correlation during the announcement minute $\left(\rho_{u, 0}=0.459\right.$ for the FTSE-DAX pair and $\rho_{u, 0}=0.505$ for the FTSE-Eurostoxx pair) may be explained by traders having diverging opinions about the impact of the released news on the direction of the prices; the traders respond then to new information according to their own views. After the initial response, contemporaneous comovements between the stock markets increase again; then investors extract the "common information" or common reaction of the market to the piece of news.

\section{INSERT TABLE 7 HERE}

Panel B of Table 7 displays the change in the contemporaneous correlation coefficients at the time of the Eurozone announcement periods. Our results do not show a significant increase in the comovements between the Eurostoxx 50 and the DAX returns when Eurozone news is released. However, as we pointed out in Section II, the contemporaneous correlation between both indices returns is very high for the whole sub-sample $(\rho=0.718)$, which indicates that these two indices tend to move in a similar way. In contrast, the results in Panel B of Table 7 indicate that the contemporaneous cross-dependences between the Eurostoxx 50 and the FTSE 100 futures more than double when Eurozone economic news is released $\left(\rho_{e, \text { before }}=0.222 v s . \rho_{e, \text { after }}=0.565\right)$. The lower correlation between both indices before the announcement releases is due to the time schedule of Eurozone news (11:00h), period in which the intraday volatility and the liquidity of both markets is relatively low.

Panel C of Table 7 characterizes the contemporaneous correlation between the DAX and the other stock indices at the time of German news announcements. As with news originating from other countries, our findings suggest that the contemporaneous correlation between indices returns increases just after the announcement releases $\left(\rho_{g, \text { before }}=0.710 v\right.$ s. $\rho_{g, \text { after }}=0.749$ for the pair DAXEurostoxx and $\rho_{g, \text { before }}=0.466 v$ s. $\rho_{g, \text { after }}=0.504$ for the pair DAX-FTSE). When we focus on the minute by minute cross-country correlations, our results show that, in contrast to news emanating from other countries, neither in the minutes leading up to the release nor at the time it takes place do the linkages between the DAX and the Eurostoxx 50 increase $\left(\rho_{g,+1}=0.582 ; \rho_{g, 0}=0.646 v s . \rho^{\mathrm{n}}=\right.$ 0.747). This result is in line with our hypothesis as German news does not have pre-set release times and investors do not know the exact minute of the release.

Summing up, in this subsection the results obtained on the effects of British, Eurozone and German announcements on stock market co-movements are compared and some general conclusions are presented. The main feature is that the impacts on stock prices of news emanating from different countries are not similar. In particular, stock market interactions at the time of economic releases depend on whether the announcements have a pre-scheduled time, as is the case with British and Eurozone releases, or they do not have a pre-set release time, like the German announcements. On the one hand, the general pattern of co-movements when British and Eurozone economic data is released is an increase on the contemporaneous cross-correlations the minute before the release, a lower correlation during the announcement minute and a new increase in stock market comovements one or two minutes after the release. On the other hand, the co-movements between the 
stock exchanges the minutes prior to German releases do not increase due to the fact that investors do not know that economic data is about to be released.

\section{Conclusions}

This study has explored the short-term dynamic interactions between the returns on the DAX, on the Eurostoxx 50 and on the FTSE 100 futures. In addition, we have analyzed the role of public macroeconomic announcements as a source of international equity market linkages. A better understanding of the transmission mechanism and the market integration when new public information arrives onto the market may provide investors with more efficient strategies to speculate or hedge with stock indices. In the first part of our empirical analysis, the dynamic spillovers between the European stock exchanges were investigated. The second part studied the effects of macroeconomic news on stock market spillovers. The third part analyzed whether crossmarket linkages remain the same or whether they increase in the minutes following the economic announcements.

The main interesting empirical patterns of international futures' return interactions found in this research are as follows:

(i) even though there are clear dynamic interactions between the DAX, the Eurostoxx 50 and the FTSE 100 futures returns, there are no profit opportunities when trading the futures on these indices. Our empirical analysis does not identify a clear dynamic trading pattern in which, for instance, the FTSE index leads the futures movements and the continental indices futures follow its movements.

(ii) domestic macroeconomic surprises significantly affect the domestic and the foreign stock returns in the short-term. The general response of the returns to both domestic and foreign news is very quick, characterized by a jump in the same minute of the release and little movement thereafter. This result is consistent with the view that equity market linkages are partially attributable to common reactions to public economic information, namely with the "public information hypothesis".

(iv) dynamic cross-market linkages between the FTSE 100, the Eurostoxx 50 and the DAX futures do not strengthen at the time of economic announcements. Specifically, the lead of a market does not strengthen around domestic macroeconomic news releases. However, the contemporaneous correlation between the three futures returns increases in the minutes after macroeconomic data is released. (iv) the fact that official announcements have pre-scheduled times, as with British and Eurozone news announcements, or non pre-scheduled times, like German news releases, affects the short-term stock market interactions around announcement periods.

Overall, our results suggest that domestic investors directly react to the content of foreign news itself, they do not wait and follow the foreign market's response to the news. This evidence supports the "public information hypothesis" as a possible source of international stock market comovements and demonstrates the importance of public economic information in explaining international equity market linkages. However, our results also suggest that returns co-movements can not be only attributable to common reactions to economic information. The stock market spillovers are much stronger than the reaction of domestic stock returns to foreign economic news. 
Generally, our results point out how important is the use of high frequency datasets to analyze and to better understand the dynamic interactions between different stock exchanges. The recent availability of new high frequency datasets from different stock exchanges provides an enormous potential for answering new questions on stock market interdependencies. As shown by the different results reported in this study, the information contained in these datasets is very rich and future research using high frequency data for analyzing stock market interactions will lead to additional interesting results. 


\section{Appendix -Table A1 \\ Macroeconomic News Releases}

This table presents the macroeconomic news releases employed in the empirical analysis. All times refer to London time. Unless otherwise stated, the announcements are reported as a month over month percentage change. ECB Financial Statement \& Balance corresponds to the previous week. Their announcement dates are 7, 14, 21 and 28 August (14.00). A priory we did not have the median expectations for these announcements, but it turns out that they always have a positive impact in the Eurex market, and therefore they were included in the positive dummy variable. On the 3 August at 11.00, final Eurozone GDP (QoQ) was announced, but expected value equals announced value. 3 July and 1 August, 11.00, the Eurozone unemployment rate was released and its expected value was equal to the actual value. In the three cases, no surprise is included in our analysis. UK GDP (QoQ) was announced at 09.30h on 27 July and 22 August. Expected value equals to actual value and therefore, the announcements are not included here. The minutes of the MPC meeting (UK) were released at $09.30 \mathrm{~h}$ on 5, 18 July and 8, 15 August. Beforehand, we do not know the sign of these releases. However, in section IV.3 these days are included in the announcement days subsample. Exactly the same situation corresponds to the release of the CIPS Service Reports and the Changes in Official Reserves, which were announced at $09.30 \mathrm{~h}$ on 4 July and 3 August.

\begin{tabular}{|c|c|c|}
\hline \multicolumn{3}{|r|}{ Positive Eurozone News Releases } \\
\hline Date & Time & Type of Announcement \\
\hline 4 July & 11.00 & EC Service Index, Business Climate Index \\
\hline 4 July & 11.00 & Eurozone PPI \\
\hline 5 July & 11.00 & Eurozone Labor Costs preliminary \\
\hline 13 July & 11.00 & Eurozone GDP rev. (QoQ) \\
\hline 18 July & 11.00 & Eurozone CPI \\
\hline 27 July & 11.00 & Eurozone Trade Balance ( Eur bln) \\
\hline 30 July & 11.00 & Eurozone Current Account (Eur bln) \\
\hline 2 August & 11.00 & Eurozone PPI \\
\hline 3 August & 09.03 & EC Purchasing Managers Index (level) \\
\hline 3 August & 11.00 & EC Service Index and Composite Index \\
\hline 20 August & 11.00 & Eurozone IP \\
\hline 30 August & 12.45 & ECB announces interest rates (cut) \\
\hline \multicolumn{3}{|r|}{ Negative Eurozone News Releases } \\
\hline Date & Time & $\begin{array}{l}\text { Type of Announcement } \\
\end{array}$ \\
\hline 3 July & 11.00 & Eurozone Sentiment Index (level) \\
\hline 3 July & 11.00 & Consumer \& Business Confidence (level) \\
\hline 4 July & 11.00 & Eurozone Retail Sales \\
\hline 5 July & 12.45 & ECB announces interest rates (no change) \\
\hline 19 July & 11.00 & Eurozone Labor Costs rev. \\
\hline 20 July & 11.00 & Eurozone IP \\
\hline 26 July & 09.00 & Eurozone M3 \\
\hline 1 August & 11.00 & Eurozone Retail Sales \\
\hline 2 August & 11.00 & Eurozone Sentiment Index, (level) \\
\hline 2 August & 11.00 & Consumer \& Business Con-dence (level) \\
\hline 2 August & 12.45 & ECB announces interest rates (no change) \\
\hline 17 August & 11.00 & Eurozone CPI \\
\hline 23 August & 11.00 & Eurozone Current Account (Eur bln) \\
\hline 28 August & 09.00 & Eurozone M3 \\
\hline \multicolumn{3}{|r|}{ Positive British News Releases } \\
\hline Date & Time & Type of Announcement \\
\hline 5 July & 09.30 & Housing Starts \\
\hline 12 July & 11.00 & BCC Quarterly Economic Survey \\
\hline 24 July & 15.30 & Conference Board. Leading and Coincident Indexes \\
\hline 26 July & 09.30 & BBA Mortgage Lending and Consumer Credit Figures \\
\hline 30 July & 09.30 & Net Consumer Credit \\
\hline 2 August & 12.00 & BoE cuts interest rates (level) \\
\hline 6 August & 09.30 & Industrial Production and Manufacturing Production \\
\hline 8 August & 10.30 & BoE Quarterly Inflation Report \\
\hline 9 August & 09.30 & Housing Starts \\
\hline
\end{tabular}




\begin{tabular}{|c|c|c|}
\hline 13 August & 09.30 & PPI Output and PPI Input \\
\hline 14 August & 09.30 & RPI \\
\hline 15 August & 09.30 & Average Earnings and Unit Wage Costs \\
\hline 16 August & 09.30 & Retail Sales \\
\hline 20 August & 09.30 & Visible Trade Balance (GPB bln) \\
\hline 21 August & 09.30 & Business Investment Figures (Q2) \\
\hline 30 August & 09.30 & M4 and New Consumer Credit \\
\hline \multicolumn{3}{|r|}{ Negative British News Releases } \\
\hline Date & Time & Type of Announcement \\
\hline 2 July & 09.30 & M0 \\
\hline 5 July & 12.00 & BoE announces interest rates (no change) \\
\hline 6 July & 09.30 & Industrial Production and Manufacturing Production \\
\hline 9 July & 09.30 & PPI Output and PPI Input \\
\hline 17 July & 09.30 & RPI \\
\hline 18 July & 09.30 & Average Earnings, Unit Wage Costs and Unemployment Change \\
\hline 19 July & 09.30 & M4, Visible Trade Balance and Budget Deficit \\
\hline 20 July & 09.30 & Retail Sales \\
\hline 25 July & 11.00 & CBI Quarterly Industrial Trends \\
\hline 30 July & 09.30 & M4 \\
\hline 2 August & 09.30 & CIPS Construction Report \\
\hline 15 August & 09.30 & Unemployment Change (thousands) \\
\hline 20 August & 09.30 & Budget De-cit (PSNCR) (GPB bln) \\
\hline 23 August & 09.30 & Conference Board. Leading and Coincident Indexes (level) \\
\hline \multicolumn{3}{|r|}{ Positive German News Releases } \\
\hline Date & Time & Type of Announcement \\
\hline 5 July & 08.50 & Employment \\
\hline 5 July & 11.00 & Factory Orders \\
\hline 9 July & 11.00 & Industrial Output \\
\hline 17 July & 15.00 & ZEW Survey (Economic Sentiment) \\
\hline 19 July & 14.22 & Factory Orders \\
\hline 24 July & 14.10 & German CPI (after Bundesländer published its own CPI) \\
\hline 24 July & 15.53 & Industrial Output \\
\hline 1 August & 08.35 & Purchasing Managers Index (level) \\
\hline 7 August & 08.28 & Unemployment Change (thousands) \\
\hline 7 August & 11.00 & Industrial Output \\
\hline 13 August & 14.00 & Capital Account and Foreign Bond Purchases \\
\hline 21 August & 15.00 & Zew Survey (Economic Sentiment) \\
\hline 22 August & 09.00 & IFO, Business Climate Index \\
\hline 23 August & 16.05 & German CPI (after landers published its own CPI) \\
\hline 31 August & 16.00 & Purchasing Managers Index (level) \\
\hline \multicolumn{3}{|r|}{ Negative German News Releases } \\
\hline Date & Time & Type of Announcement \\
\hline 2 July & 08.30 & Purchasing Managers Index (level) \\
\hline 2 July & 14.30 & Industrial Output \\
\hline 5 July & 08.25 & Unemployment Change (thousands) \\
\hline 12 July & 09.12 & CPI (final) \\
\hline 12 July & 12.15 & Capital Account and Foreign Bond Purchases \\
\hline 20 July & 08.26 & Construction Orders \\
\hline 23 July & 09.00 & IFO, Business Climate Index \\
\hline 31 July & 08.05 & VDMA Plant and Machinery Orders \\
\hline 6 August & 11.00 & Factory Orders \\
\hline 7 August & 08.50 & Employment \\
\hline 17 August & 09.09 & New Car Registration \\
\hline 29 August & 10.22 & VDMA Plant and Machinery Orders \\
\hline 29 August & 14.30 & Conference Board Leading and Coincident Index \\
\hline
\end{tabular}




\section{References}

Abhyankar, A. (1995): "Returns and Volatility Dynamics in the FTSE Stock Index and Stock Index Futures Markets", Journal of Futures Markets, 15(4), pp. 457-488.

Almeida, A., C. Goodhart, and R. Payne (1998): "The Effects of Macroeconomic News on High Frequency Exchange Rate Behavior", Journal of Financial and Quantitative Analysis, 33(3), pp. 383-408.

Ammer, J., and J. Mei (1996): "Measuring International Economic Linkages with Stock Market Data", Journal of Finance, 51(5), pp. 1743-1763.

Andersen, T., T. Bollerslev, F. Diebold, and C. Vega (2003): "Micro Effects of Macro Announcements: Real Time Price Discovery in Foreign Exchange", American Economic Review, 93(1), pp. 38-62.

Becker, K., J. Finnerty, and J. Friedman (1995): "Economic News and Equity Market Linkages between the US and the UK", Journal of Banking and Finance, 19(7), pp. 1191-1210.

Bekaert, G., and C. Harvey (1995): “Time-Varying World Market Integration”, Journal of Finance, 50(2), pp. 403-444.

Biais, B., L. Glosten, and C. Spratt (2005): "Market Micostructure: A Survey of Microfoundations, Empirical Results, and Policy Implications”, Journal of Financial Markets, 8(2), pp. 217-264.

Bonfiglioli, A., and C. Favero (2005): "Explaining Co-movements between Stock Markets: The Case of US and Germany", Journal of International Money and Finance, 24(8), pp. 1299-1316.

Buckle, M., O. Gwilym, S. Thomas, and M. Woodhams (1998): "Empirical Regularities in Interest Rate and Equity Index Futures Markets and the Effect of Macroeconomic Announcements", Journal of Business Finance and Accounting, 25(7\&8), pp. 921-942.

Campbell, J., and Y. Hamao (1992): "Predictable Stock Returns in the United States and Japan: a Study of Long-term Capital Market Integration”, Journal of Finance, 47(1), pp. 43-69.

Chen, G., M. Firth, and O. Meng Rui (2002): "Stock Market Linkages: Evidence from Latin America”, Journal of Banking and Finance, 26(6), pp. 1113-1141.

Clare, A., and R. Courtenay (2001): “Assessing the Impact of Macroeconomic News Announcements on Security Prices under Different Monetary Policy Regimes", Working Paper, No. 125, Bank of England.

Connolly, R., and A. Wang (2003): "International Equity Market Comovements: Economic Fundamentals or Contagion?", Pacific-Basin Finance Journal, 11(1), pp. 23-43.

Engle, R., C. Granger (1987): "Cointegration and Error Correction: Representation, Estimation and Testing”, Econometrica, 55(2), pp. 251-276.

Eun, C., and S. Shim (1989): "International Transmission of Stock Market Movements", Journal of Financial and Quantitative Analysis, 24(2), pp. 241-256.

Francis, B., and L. Leachman (1998): "Superexogeneity and the Dynamic Linkages among International Equity Markets", Journal of International Money and Finance, 17(3), pp. 475492.

Gerrits, R., and A. Yuce (1999): "Short and Long Term Links among European and US Stock Markets", Applied Financial Economics, 9(1), pp. 1-9. 
Goodhart, C., S. Hall, S. Henry, and B. Pesaran (1993): "News Effects in a High-Frequency Model of the Sterling-Dollar Exchange Rate", Journal of Applied Econometrics, 8(1), pp. 1-13.

Glosten, L., and P. Milgrom (1985): "Bid, Ask and Transaction Prices in a Specialist Market with Heterogeneous Informed Traders", Journal of Financial Economics, 14(1), pp. 71-100.

Grubel, H., and K. Fadner (1971): "The Interdependence of International Equity Markets", Journal of Finance, 26(1), pp. 89-94.

Gwilym, O., and M. Buckle (2001): "The Lead-Lag Relationship between the FTSE 100 Stock Index and its Derivative Contracts", Applied Financial Economics, 11(4), pp. 385-393.

Hasbrouck, J. (2003): "Intraday Price Formation in US Equity Index Markets", Journal of Finance, 58(6), pp. 2375-2400.

Johansen, S. (1991): "Estimation and Hypothesis Testing of Cointegration Vectors in Gaussian Vector Autoregressive Models", Econometrica, 59(6), pp. 1551-1580.

Johansen, S. (1988): "Statistical Analysis of Cointegration Vectors", Journal of Economics Dynamics and Control, 12(2-3), pp. 231-254.

Karolyi, G., and R. Stulz (1996): "Why Do Markets Move Together? An Investigation of U.S.Japan Stock Return Co-movements", Journal of Finance, 51(3), pp. 951-985.

Kasa, K. (1992): "Common Stochastic Trends in International Stock Markets", Journal of Monetary Economics, 29(1), pp. 95-124.

King, M., and S. Wadhwani (1990): “Transmission of Volatility between Stock Markets", Review of Financial Studies, 3(1), pp. 5-33.

Madhavan, A. (2000): "Market Microstructure: A Survey", Journal of Financial Markets, 3(3), pp. 205-258.

Malliaris, A., and J. Urrutia (1992): "The International Crash of October 1987: Causality Tests", Journal of Financial and Quantitative Analysis, 27(3), pp. 353-364.

Masih, A., and R. Masih (1999): “Are Asian Stock Market Fluctuations Due Mainly to IntraRegional Contagion Effects? Evidence based on Asian Emerging Stock Markets", PacificBasin Finance Journal, 7(3-4), pp. 251-282.

McQueen, G., and V. Roley (1993): "Stock Prices, News and Business Conditions", Review of Financial Studies, 6(3), pp. 683-707.

Pesaran, H., and Y. Shin (1998): "Generalized Impulse Response Analysis in Linear Multivariate Models”, Economic Letters, 58(1), pp. 17-29.

Rigobon, R., and B. Sack (2004): “The Impact of Monetary Policy on Asset Prices", Journal of Monetary Economics, 51(8), pp. 1553-1575.

Stoll, H. (2003): "Market Microstructure" in G. Constantinides, M. Harris, and R. Stulz (eds.): Handbook of the Economics of Finance, Volume 1A, chapter 9, Elsevier North-Holland, Harvard. 
Table 1

\section{Descriptive Statistics}

Descriptive statistics of the returns are reported in Table 1A. $R_{D A X}$ stands for DAX futures returns, $R_{E u r}$ for Eurostoxx futures returns and $R_{F T S E}$ for FTSE futures returns. Table 1B reports the sample autocorrelations of the futures price series and of the futures returns series for the DAX, the Eurostoxx 50 and the FTSE 100 stock indexes. All of the autocorrelations of prices are significant at the 1 percent level. The lower part of Table 1B documents the autocorrelations of the futures returns. For the returns autocorrelations, ** and * denote significance at the 5 and 10 percent levels, respectively. Table $1 \mathrm{C}$ provides the correlation matrix of the stock index futures between the three markets.

Table 1A: Minute by minute returns distribution

\begin{tabular}{ccccccc}
\hline & Mean & Std. Dev. & Skew & Kurtosis & Maximum & Minimum \\
\hline$R_{D A X}$ & $-3.5 .10^{-5}$ & 0.0005 & -0.012 & 8.293 & 0.0075 & -0.0054 \\
$R_{\text {Eur }}$ & $-4.0 .10^{-6}$ & 0.0005 & 0.0264 & 6.318 & 0.0049 & -0.0041 \\
$R_{\text {FTSE }}$ & $1.5 .10^{-7}$ & 0.0004 & 0.0418 & 7.565 & 0.0053 & -0.0046
\end{tabular}

Table 1B: Autocorrelations

\begin{tabular}{cccccc}
\hline \hline & $k=1$ & $k=2$ & $k=3$ & $k=4$ & $k=5$ \\
\hline$P_{D A X}$ & 1.000 & 1.000 & 0.999 & 0.999 & 0.998 \\
$P_{\text {Eur }}$ & 1.000 & 0.999 & 0.999 & 0.999 & 0.998 \\
$P_{F T S E}$ & 0.999 & 0.999 & 0.998 & 0.998 & 0.997 \\
$R_{D A X}$ & $0.030^{*}$ & $0.016^{* *}$ & -0.009 & -0.011 & -0.002 \\
$R_{\text {Eur }}$ & $0.035^{*}$ & $0.025^{*}$ & 0.008 & -0.002 & 0.006 \\
$R_{\text {FTSE }}$ & $-0.014^{* *}$ & $0.017^{* *}$ & 0.010 & 0.012 & 0.004
\end{tabular}

Table 1C: Contemporaneous correlation

\begin{tabular}{cccc}
\hline \hline & $R_{D A X}$ & $R_{\text {Eur }}$ & $R_{F T S E}$ \\
\hline$R_{D A X}$ & 1 & 0.718 & 0.394 \\
$R_{\text {Eur }}$ & & 1 & 0.375 \\
$R_{\text {FTSE }}$ & & & 1
\end{tabular}


Table 2

Unit Root and Cointegration Tests

Table 2A details the Augmented Dickey Fuller (ADF) unit root tests of stationarity in the levels and first differences of the futures price series (in natural log form) of the DAX, the Eurostoxx 50 and the FTSE 100. The test equations include both intercept and trend. The lag length in the ADF regression is set to three, four and two respectively in accordance to the Akaike Information Criteria (AIC). The 5 percent Mackinnon critical values for rejection of hypothesis of a unit root is -3.41 . *** indicates significance at the 1 percent level. The Johansen Cointegration test for each pair of prices is recorded in Table 2B. To estimate the number of cointegration relations, Johansen $(1988,1991)$ proposes two methods: the trace test and the maximal eigenvalues test. The test statistic examines the hypothesis of zero cointegration relations against the alternative of that all the series are stationary. The maximum eigenvalue statistic tests the hypothesis of zero cointegration relations against the alternative of one cointegration relation. Table $2 \mathrm{~B}$ notes for each pair of prices the trace statistic in the first row and the maximum eigenvalue statistic in the second row. For each test, the maximum eigenvalue, the likelihood ratio test statistic and the five percent level critical values are detailed. The tests allow for linear trends in the original price series but not in the cointegration equations.

Table 2A: Augmented Dickey Fuller unit root test

\begin{tabular}{cccc}
\hline \hline & $P_{D A X}$ & $P_{\text {Eur }}$ & $P_{F T S E}$ \\
\hline ADF levels & -2.43 & -2.53 & -2.67 \\
ADF First Differences & $-67.4 * * *$ & $-67.0 * * *$ & $-65.2 * * *$
\end{tabular}

Table 2B: Johansen cointegration test

\begin{tabular}{cccccc}
\hline Pair & Eigenvalues & $\begin{array}{c}\text { Likelihood } \\
\text { Ratio }\end{array}$ & $\begin{array}{c}\text { CriticalValue } \\
\text { 5\% level }\end{array}$ & $\begin{array}{c}H_{0} \\
\text { No. of CE }(r)\end{array}$ & $H_{A}$ \\
\hline Eur-DAX & 0.0004 & 9.33 & 15.41 & $r=0$ & Stationary \\
& 0.0004 & 9.32 & & $r=0$ & $r=1$ \\
Eur-FTSE & 0.0004 & 10.82 & 15.41 & $r=0$ & Stationary \\
& 0.0004 & 8.94 & & $r=0$ & $r=1$ \\
DAX-FTSE & 0.0003 & 7.34 & 15.41 & $r=0$ & Stationary \\
& 0.0003 & 7.34 & & $r=0$ & $r=1$
\end{tabular}


Table 3

Granger Causality Tests

Table 3 reports the $F$-statistics of the Granger Causality Tests. It is tested as to whether returns in market $i$ are jointly significant in the equation for returns in market $j$, which is equivalent to test if all the past coeffcients in the VAR equations are jointly significant or not.

\begin{tabular}{lcc}
\multicolumn{1}{c}{ Hypothesis } & $F$-Statistic & Probability \\
\hline$R_{D A X}$ does not Granger cause $R_{\text {Eur }}$ & 26.25 & 0.000 \\
$R_{D A X}$ does not Granger cause $R_{F T S E}$ & 46.58 & 0.000 \\
$R_{E u r}$ does not Granger cause $R_{D A X}$ & 20.65 & 0.000 \\
$R_{E u r}$ does not Granger cause $R_{F T S E}$ & 49.08 & 0.000 \\
$R_{F T S E}$ does not Granger cause $R_{D A X}$ & 7.55 & 0.000 \\
$R_{F T S E}$ does not Granger cause $R_{\text {Eur }}$ & 10.07 & 0.000
\end{tabular}

Table 4

Generalized Variance Decomposition

Variance decomposition of a one-standard deviation shock to each market is listed in Table 4. The forecasting horizons are given for one to five minutes, ten and fifteen minutes ahead. Each row displays the forecasted error variance explained by the market in the column heading. The last column, labeled Foreign markets, shows the percentage of forecast error variance of the market in the first column explained by all other markets except the market's own innovations.

\begin{tabular}{|c|c|c|c|c|c|c|}
\hline \multirow{2}{*}{$\begin{array}{l}\text { Decomp. } \\
\text { of: }\end{array}$} & \multirow[t]{2}{*}{ Period } & \multirow{2}{*}{$\begin{array}{l}\text { Std. Error } \\
\quad * 1,000\end{array}$} & \multicolumn{3}{|c|}{ Due to a shock in: } & \multirow{2}{*}{$\begin{array}{c}\text { Foreign } \\
\text { markets }_{t}(\%)\end{array}$} \\
\hline & & & $R_{D A X, t}(\%)$ & $R_{\text {Eur }, t}(\%)$ & $R_{F T S E, t}(\%)$ & \\
\hline \multirow[t]{7}{*}{$\sigma_{D A X}$} & $t+1$ & 0.535 & 56.6 & 32.4 & 10.8 & 43.8 \\
\hline & $t+2$ & 0.538 & 56.4 & 32.6 & 10.9 & 43.5 \\
\hline & $t+3$ & 0.538 & 56.3 & 32.6 & 10.9 & 43.6 \\
\hline & $t+4$ & 0.538 & 56.3 & 32.6 & 10.9 & 43.6 \\
\hline & $t+5$ & 0.538 & 56.3 & 32.6 & 10.9 & 43.6 \\
\hline & $t+10$ & 0.539 & 56.3 & 32.6 & 10.9 & 43.6 \\
\hline & $t+15$ & 0.539 & 56.3 & 32.6 & 10.9 & 43.6 \\
\hline \multirow[t]{7}{*}{$\sigma_{\text {Eur }}$} & $t+1$ & 0.540 & 32.8 & 57.2 & 9.9 & 42.7 \\
\hline & $t+2$ & 0.544 & 33.0 & 56.8 & 10.1 & 43.1 \\
\hline & $t+3$ & 0.544 & 33.0 & 56.8 & 10.1 & 43.1 \\
\hline & $t+4$ & 0.544 & 33.0 & 56.8 & 10.1 & 43.1 \\
\hline & $t+5$ & 0.544 & 33.0 & 56.8 & 10.1 & 43.1 \\
\hline & $t+10$ & 0.545 & 33.0 & 56.8 & 10.1 & 43.2 \\
\hline & $t+15$ & 0.545 & 33.0 & 56.8 & 10.1 & 43.2 \\
\hline \multirow[t]{7}{*}{$\sigma_{F T S E}$} & $\mathrm{t}+1$ & 0.415 & 14.0 & 12.7 & 73.2 & 26.7 \\
\hline & $t+2$ & 0.419 & 14.6 & 13.4 & 71.9 & 28.0 \\
\hline & $t+3$ & 0.419 & 14.6 & 13.5 & 71.8 & 28.1 \\
\hline & $t+4$ & 0.419 & 14.6 & 13.5 & 71.7 & 28.2 \\
\hline & $t+5$ & 0.420 & 14.6 & 13.5 & 71.7 & 28.2 \\
\hline & $t+10$ & 0.420 & 14.6 & 13.5 & 71.7 & 28.2 \\
\hline & $t+15$ & 0.420 & 14.6 & 13.5 & 71.7 & 28.2 \\
\hline
\end{tabular}


Table 5

VAR Estimates. Effects of the News on Stock Returns

Parameter estimates from VAR system (2): $R_{j, t}=\alpha_{j}+\sum_{j=1}^{3} \sum_{r=1}^{K} \beta_{j, r} R_{j, t-r}+\sum_{i=1 s=0}^{6} \sum_{i, s}^{10} \theta_{i, t-s}+u_{j, t}^{n e}$

Panel A reports the cumulative effect of each category of news on the future prices. The $F$-statistics testing the null hypothesis that the sum of the lagging coefficients on the news variables is equal to zero are also given. Panel B displays the effects of the news on stock returns at the same minute of the release and up to two minutes afterwards. All the estimated coefficients not reported in the table turn out not to be significant. The first two columns of this table refer to the DAX equation. Columns three and four pertain to the Eurostoxx 50 equation and columns five and six relate to the FTSE 100 equation. For sake of space not all the coefficients of the new estimations are reported. For notational convenience, the subscripts $i$ are replaced by each category of news, namely $g p$ stands for positive German news, gn denotes negative German news, up represents positive British announcements and so forth. For instance, with this notation, $\theta_{e p, 0}$ is the coefficient that corresponds to the positive Eurozone news dummy the minute when the news is released. In the same way, $\theta_{u n,-2}$ is the coefficient that corresponds to the negative British news dummy two minutes after the releases. Note that the news series are included as new exogenous variables in the VAR system. As they are uncorrelated with the error and they are independent of the past, their inclusion does not change the $\beta_{j, r}$ coefficients estimated in the previous subsection IV.1. All the coefficients and the standard deviations presented in this table are multiplied per 1,000 . HAC consistent standard errors are reported. $*$, ** and *** indicate significance at the the 10 , the 5 and the 1 percent levels, respectively.

\begin{tabular}{|c|c|c|c|c|c|c|}
\hline \multicolumn{7}{|c|}{ Panel A: Cumulative coefficients and $F$-statistics } \\
\hline & \multicolumn{2}{|c|}{ 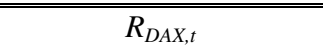 } & \multicolumn{2}{|c|}{$R_{E u r, t}$} & \multicolumn{2}{|c|}{ 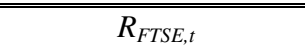 } \\
\hline & Coef. & $F$-Stat. & Coef. & $F$-Stat. & Coef. & $F$-Stat. \\
\hline$\theta_{u p, 0 \ldots-10}$ & $0.991 * *$ & 1.945 & $0.963^{*}$ & $1.675^{*}$ & $1.341 * * *$ & 4.961 \\
\hline$\theta_{u n, 0 \ldots-10}$ & -0.095 & 0.849 & -0.124 & 0.616 & -0.151 & 1.531 \\
\hline$\theta_{e p, 0 \ldots-10}$ & 0.568 & 1.552 & 0.579 & $4.262 * * *$ & 0.376 & 1.083 \\
\hline$\theta_{e n, 0 \ldots-10}$ & $-0.640 * * *$ & 3.889 & -0.941 & $4.330 * * *$ & -0.819 & 1.432 \\
\hline$\theta_{g p, 0 \ldots-10}$ & $1.092 * * *$ & 2.948 & 0.711 & $2.342 * * *$ & $0.272 * * *$ & 1.903 \\
\hline$\theta_{g n, 0 \ldots-10}$ & $-0.783 * *$ & 2.127 & -0.342 & $2.187 * *$ & -0.960 & 1.524 \\
\hline \multicolumn{7}{|c|}{ Panel B: Effect of news on stock returns } \\
\hline & \multicolumn{2}{|c|}{$R_{D A X, t}$} & \multicolumn{2}{|c|}{$R_{E u r, t}$} & \multicolumn{2}{|c|}{$R_{F T S E, t}$} \\
\hline & Coef. & Std. Error & Coef. & Std. Error & Coef. & Std. Error \\
\hline$\theta_{u p, 0}$ & $0.456^{* *}$ & 0.192 & $0.438 * *$ & 0.210 & $0.718 * *$ & 0.370 \\
\hline$\theta_{u p,-1}$ & $0.328 * *$ & 0.123 & $-0.254 * *$ & 0.135 & $0.205^{* * *}$ & 0.087 \\
\hline$\theta_{u p,-2}$ & -0.041 & 0.129 & 0.032 & 0.151 & 0.254 & 0.125 \\
\hline$\theta_{u n, 0}$ & -0.281 & 0.210 & $-0.287^{*}$ & 0.183 & $-0.317 * * *$ & 0.116 \\
\hline$\theta_{u n,-1}$ & 0.076 & 0.146 & -0.042 & 0.159 & 0.151 & 0.139 \\
\hline$\theta_{u n,-2}$ & 0.097 & 0.167 & 0.086 & 0.071 & -0.082 & 0.081 \\
\hline$\theta_{e p, 0}$ & $0.549 * * *$ & 0.141 & $0.938 * * *$ & 0.257 & $0.247 * * *$ & 0.078 \\
\hline$\theta_{e p,-1}$ & -0.225 & 0.177 & $0.462^{*}$ & 0.261 & -0.185 & 0.183 \\
\hline$\theta_{e p,-2}$ & 0.162 & 0.126 & 0.099 & 0.165 & 0.083 & 0.093 \\
\hline$\theta_{e n, 0}$ & $-0.952 * * *$ & 0.331 & $-1.092 * * *$ & 0.302 & -0.046 & 0.295 \\
\hline$\theta_{e n,-1}$ & -0.137 & 0.242 & -0.170 & 0.189 & 0.015 & 0.117 \\
\hline$\theta_{e n,-2}$ & $-0.344^{*}$ & 0.209 & 0.087 & 0.171 & -0.093 & 0.113 \\
\hline$\theta_{g p, 0}$ & 0.297 & 0.215 & 0.274 & 0.235 & $0.243 * *$ & 0.114 \\
\hline$\theta_{g p,-1}$ & $0.333^{* *}$ & 0.173 & $0.301^{*}$ & 0.165 & $0.298 * *$ & 0.121 \\
\hline$\theta_{g p,-2}$ & 0.156 & 0.193 & 0.232 & 0.163 & 0.932 & 0.154 \\
\hline$\theta_{g n, 0}$ & $-0.472 * *$ & 0.217 & $-0.494 * * *$ & 0.150 & $-0.395 * * *$ & 0.132 \\
\hline$\theta_{g n,-1}$ & $-0.406^{* * *}$ & 0.166 & -0.382 & 0.238 & 0.041 & 0.129 \\
\hline$\theta_{g n,-2}$ & -0.026 & 0.210 & 0.008 & 0.246 & 0.064 & 0.105 \\
\hline
\end{tabular}




\section{Table 6}

\section{VAR Estimates. Effects of News on the Lead-Lag Relationship between Future Returns}

Parameter estimates from VAR system (3): $R_{j, t}=\alpha_{j}+\sum_{j=1}^{3} \sum_{r=1}^{K}\left(\beta_{j, r}^{0}+\beta_{j, r}^{1} x_{t}^{n e}\right) R_{j, t-r}+u_{j, t}$

Panel A reports the cumulative coefficient and the $F$-statistics testing the null hypothesis that the sum of the lagging coefficients is equal to zero. Panel B reports the estimated coefficients $\beta_{i,-1}^{1}$ to $\beta_{i,-3}^{1}$ on the interaction variables for each category of news. The first two columns refer to the DAX equation, the third and fourth column refer to the Eurostoxx 50 equation and the last two columns refer to the FTSE 100 equation. HAC consistent standard errors are reported. $* * *$ and $* * *$ indicate significance at the 10,5 and 1 percent levels, respectively.

\begin{tabular}{|c|c|c|c|c|c|c|}
\hline \multicolumn{7}{|c|}{ Panel A: Cumulative coeffcients and $F$-statistics } \\
\hline & \multicolumn{2}{|c|}{$R_{D A X, t}$} & \multicolumn{2}{|c|}{$R_{E u r, t}$} & \multicolumn{2}{|c|}{$R_{F T S E, t}$} \\
\hline & Coef. & $F$-Stat. & Coef. & $F$-Stat. & Coef. & $F$-Stat. \\
\hline$\beta_{u p,-1 \ldots-10}^{1}$ & 0.135 & 1.180 & 0.076 & 1.010 & $-0.066^{*}$ & 1.660 \\
\hline$\beta_{u n,-1 \ldots-10}^{1}$ & -0.022 & 1.017 & 0.127 & 1.338 & -0.010 & 1.396 \\
\hline$\beta_{e p,-1 \ldots-10}^{1}$ & $-0.281 * *$ & 2.212 & $-0.422 * * *$ & 3.928 & $-0.195^{*}$ & 1.574 \\
\hline$\beta_{e n,-1 \ldots-10}^{1}$ & -0.126 & 1.096 & -0.235 & 1.265 & $-0.038 * *$ & 2.260 \\
\hline$\beta_{g p,-1 \ldots-10}^{1}$ & -0.005 & 0.841 & $0.154^{*}$ & 1.570 & $-0.221 *$ & 1.652 \\
\hline$\beta_{g n,-1 \ldots-10}^{1}$ & -0.072 & 1.165 & -0.207 & 1.155 & -0.245 & 0.437 \\
\hline \multicolumn{7}{|c|}{ Panel B: Effect of news on stock returns spillovers } \\
\hline & \multicolumn{2}{|c|}{$R_{D A X, t}$} & \multicolumn{2}{|c|}{$R_{E u r, t}$} & \multicolumn{2}{|c|}{$R_{F T S E, t}$} \\
\hline & Coef. & Std. Error & Coef. & Std. Error & Coef. & Std. Error \\
\hline$\beta_{u p,-1}^{1}$ & -0.002 & 0.083 & -0.099 & 0.063 & & \\
\hline$\beta_{u p,-2}^{1}$ & 0.018 & 0.062 & 0.041 & 0.072 & & \\
\hline$\beta_{u p,-3}^{1}$ & -0.040 & 0.081 & -0.011 & 0.066 & & \\
\hline$\beta_{u n,-1}^{1}$ & -0.024 & 0.081 & 0.004 & 0.079 & & \\
\hline$\beta_{u n,-2}^{1}$ & 0.002 & 0.066 & -0.017 & 0.059 & & \\
\hline$\beta_{u n,-3}^{1}$ & -0.053 & 0.068 & -0.026 & 0.061 & & \\
\hline$\beta_{e p,-1}^{1}$ & 0.068 & 0.086 & & & 0.002 & 0.063 \\
\hline$\beta_{e p,-2}^{1}$ & 0.009 & 0.095 & & & 0.022 & 0.058 \\
\hline$\beta_{e p,-3}^{1}$ & -0.175 & 0.121 & & & -0.116 & 0.080 \\
\hline$\beta_{e n,-1}^{1}$ & -0.029 & 0.103 & & & 0.066 & 0.047 \\
\hline$\beta_{e n,-2}^{1}$ & -0.017 & 0.083 & & & -0.084 & 0.054 \\
\hline$\beta_{e n,-3}^{1}$ & -0.085 & 0.060 & & & 0.065 & 0.043 \\
\hline$\beta_{g p,-1}^{1}$ & & & 0.025 & 0.067 & -0.052 & 0.048 \\
\hline$\beta_{g p,-2}^{1}$ & & & -0.011 & 0.068 & -0.024 & 0.044 \\
\hline$\beta_{g p,-3}^{1}$ & & & -0.003 & 0.067 & -0.074 & 0.046 \\
\hline$\beta_{g n,-1}^{1}$ & & & -0.076 & 0.080 & -0.047 & 0.057 \\
\hline$\beta_{g n,-2}^{1}$ & & & -0.027 & 0.077 & -0.077 & 0.066 \\
\hline$\beta_{g n,-3}^{1}$ & & & -0.121 & 0.077 & -0.071 & 0.050 \\
\hline
\end{tabular}


Table 7

Contemporaneous Cross-Market Correlations at the Time of Releases

Panel A presents the contemporaneous correlation coefficients for the pairs FTSE-DAX and FTSE-Eurostoxx at about the time of the British announcement minutes. The coefficient $\rho_{u \text {,before }}$ depicts the contemporaneous correlation between the pairs FTSE-DAX (column one) and FTSE-Eurostoxx (column two) five minutes before the news is released. Similarly, the coefficient $\rho_{u, \text { after }}$ describes the returns' contemporaneous correlation in the five minutes after the announcements are released. Additionally, minute by minute contemporaneous correlation is also reported in this table. For instance, the coefficient $\rho_{u, 0}$ describes the contemporaneous correlation in the exact minute the news is released. Similarly, the coefficient $\rho_{u,+1}$ is the contemporaneous correlation one minute before British releases and the coefficient $\rho_{u,-2}$ depicts the contemporaneous correlation two minutes after the British announcements. Panel B presents the changes on contemporaneous correlations around Eurozone releases. Panel $\mathrm{C}$ characterizes the contemporaneous correlation between the DAX and the other stock indices at the time of German news announcements. Note that in this table no distinction is made between positive and negative news. All coefficients are significant at the 1 percent level. Only the coefficients with ${ }^{b}$ are not significant at the 1 percent level.

\begin{tabular}{|c|c|c|}
\hline \multicolumn{3}{|c|}{ Panel A: British news is released } \\
\hline & $R_{F T S E, t}-R_{D A X, t}$ & $R_{F T S E, t}-R_{E u r, t}$ \\
\hline$\rho_{u, \text { before }}$ & 0.452 & 0.315 \\
\hline$\rho_{u, a f t e r}$ & 0.492 & 0.539 \\
\hline$\rho_{u,+1}$ & 0.776 & 0.777 \\
\hline$\rho_{u, 0}$ & 0.459 & 0.505 \\
\hline$\rho_{u,-1}$ & 0.702 & 0.565 \\
\hline$\rho_{u,-2}$ & 0.525 & 0.536 \\
\hline \multicolumn{3}{|c|}{ Panel B: Eurozone news is released } \\
\hline & $\overline{R_{E u r, t}-R_{D A X, t}}$ & $\overline{R_{E u r, t}-R_{F T S E, t}}$ \\
\hline$\rho_{e, \text { before }}$ & 0.733 & $0.222^{b}$ \\
\hline$\rho_{e, \text { after }}$ & 0.738 & 0.565 \\
\hline$\rho_{e,+1}$ & 0.748 & 0.289 \\
\hline$\rho_{e, 0}$ & 0.584 & $0.387^{b}$ \\
\hline$\rho_{e,-1}$ & 0.490 & 0.303 \\
\hline$\rho_{e,-2}$ & 0.793 & $0.181^{b}$ \\
\hline \multicolumn{3}{|c|}{ Panel C: German news is released } \\
\hline & $R_{D A X, t}-R_{E u r, t}$ & $R_{D A X, t}-R_{F T S E, t}$ \\
\hline$\rho_{g, \text { before }}$ & 0.710 & 0.465 \\
\hline$\rho_{g, a f t e r}$ & 0.749 & 0.504 \\
\hline$\rho_{g,+1}$ & 0.582 & 0.381 \\
\hline$\rho_{g, 0}$ & 0.646 & 0.354 \\
\hline$\rho_{g,-1}$ & 0.952 & 0.511 \\
\hline$\rho_{g,-2}$ & 0.757 & 0.389 \\
\hline
\end{tabular}




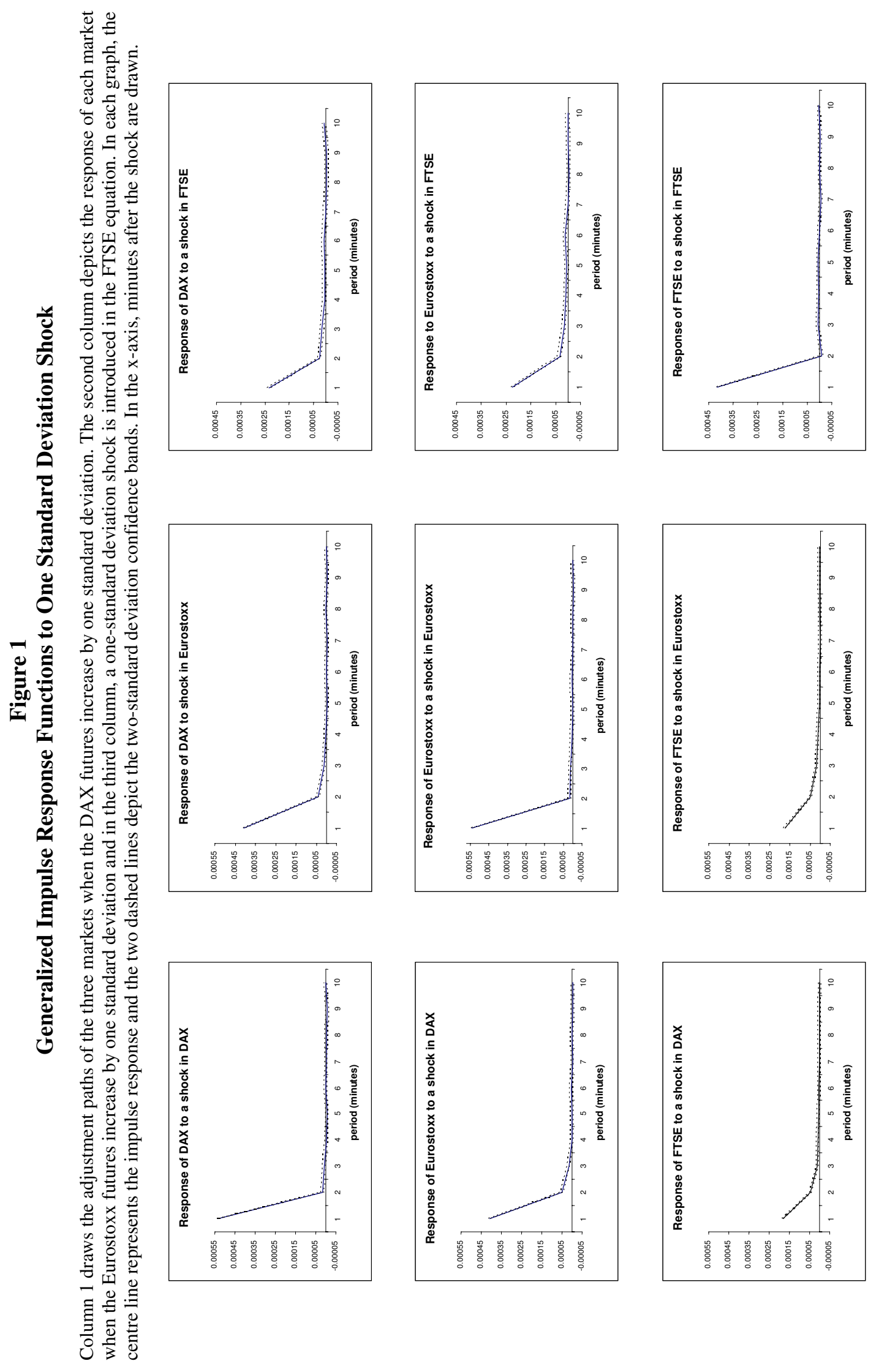




\section{CFS Working Paper Series:}

\begin{tabular}{|c|c|c|}
\hline No. & Author(s) & Title \\
\hline $2006 / 24$ & $\begin{array}{l}\text { Toker Doganoglu } \\
\text { Christoph Hartz } \\
\text { Stefan Mittnik }\end{array}$ & $\begin{array}{l}\text { Portfolio Optimization when Risk Factors are } \\
\text { Conditionally Varying and Heavy Tailed }\end{array}$ \\
\hline $2006 / 23$ & $\begin{array}{l}\text { Christoph Hartz } \\
\text { Stefan Mittnik } \\
\text { Marc S. Paolella }\end{array}$ & $\begin{array}{l}\text { Accurate Value-at-Risk Forecasting Based on the } \\
\text { (good old) Normal-GARCH Model }\end{array}$ \\
\hline $2006 / 22$ & $\begin{array}{l}\text { Dirk Krueger } \\
\text { Hanno Lustig } \\
\text { Fabrizio Perri }\end{array}$ & $\begin{array}{l}\text { Evaluating Asset Pricing Models with Limited } \\
\text { Commitment using Household Consumption Data }\end{array}$ \\
\hline $2006 / 21$ & $\begin{array}{l}\text { Juan Carlos Conesa } \\
\text { Sagiri Kitao } \\
\text { Dirk Krueger }\end{array}$ & Taxing Capital? Not a Bad Idea After All! \\
\hline $2006 / 20$ & $\begin{array}{l}\text { Annamaria Lusardi } \\
\text { Olivia S. Mitchell }\end{array}$ & $\begin{array}{l}\text { Baby Boomer Retirement Security: The Roles of } \\
\text { Planning, Financial Literacy, and Housing Wealth }\end{array}$ \\
\hline 2006/19 & $\begin{array}{l}\text { Carol C. Bertaut } \\
\text { Michael Haliassos }\end{array}$ & Credit Cards: Facts and Theories \\
\hline $2006 / 18$ & $\begin{array}{l}\text { Dirk Krueger } \\
\text { Alexander Ludwig }\end{array}$ & $\begin{array}{l}\text { On the Consequences of Demographic Change for } \\
\text { Rates of Returns to Capital, and the Distribution of } \\
\text { Wealth and Welfare }\end{array}$ \\
\hline 2006/17 & $\begin{array}{l}\text { Franklin Allen } \\
\text { Elena Carletti }\end{array}$ & Mark-to-Market Accounting and Liquidity Pricing \\
\hline $2006 / 16$ & $\begin{array}{l}\text { Erik Hurst } \\
\text { Arthur Kennickell } \\
\text { Annamaria Lusardi } \\
\text { Francisco Torralba }\end{array}$ & $\begin{array}{l}\text { Precautionary Savings and the Importance of } \\
\text { Business Owners }\end{array}$ \\
\hline 2006/15 & $\begin{array}{l}\text { Arthur Kennickell } \\
\text { Annamaria Lusardi }\end{array}$ & $\begin{array}{l}\text { Disentangling the Importance of the Precautionary } \\
\text { Saving Motive }\end{array}$ \\
\hline
\end{tabular}

Copies of working papers can be downloaded at http://www.ifk-cfs.de 